DOI: 10.35218/armca.2019.1.04

\title{
To Believe and to Govern or the Oikonomic Sense of the Image of Power*
}

\section{Laura Mesina**}

\begin{abstract}
The medieval imaginary emerged as a corpus of discursive formations, which do not always have a strictly Byzantine source. Some elements of ethics and justice, of social organization or relationship between the perceptible and the non-perceptible, of understanding the divine and correlation with ethical faith and duty, have their roots in the philosophical imaginary of the ancient political system, the first system that aimed at the construction of a model of civic society. The "inheritance" at the level of the collective imaginary is, thus, not only Christian, but also ancient.

Without having established an unmediated scientific relationship with the ancient texts whence the philosophical imaginary of the political can be extracted the medieval Romanian power followed the natural community formation routes, which were derived from a social model. This type of organization was re-interpreted by the philosophers of Christian power and theologically included in the oikonomic plan.

The practical interpretation given by Romanian lawmakers to some of the post-Byzantine political ideas aimed at an adaptation of those discursive formations, which governed the trans-state collective imaginary in the area of influence of the empire ${ }^{l}$. The Romanian imaginary itself will spring from these intersections between a normal line of socio-economic coalescence and a political plan for the formation of a state unit with its own acknowledged "national" identity, under the influence of the "basileic chimera". Finally, the "history of the imperial idea for the Romanians will be that of a compromise between a political ideal and practical realities" ${ }^{2}$.
\end{abstract}

Keywords: imaginary, Byzantine empire, imperial image, oikonomia, Romanian medieval states, Romanian medieval imaginary

\footnotetext{
* This article was originally published in the Annuario dell' Istituto Romeno di Cultura e Ricerca Umanistica ,Nicolae Iorga di Venezia, IX/2007, edited by Corina Gabriela Bădiliță, Cristian Alexandru Damian, and Monica Joița, Editura Academiei Române, București, 2008, p. 445-470.

${ }^{* *}$ Laura Mesina, PhD (Philology), Associate Professor of the Doctoral School „Space, Image, Text, Territory", Center of Excellence in Study of Image \& Faculty of Letters, University of Bucharest, 5-7 Edgar Quinet Street, 030167 Sector 2, Bucharest, Romania, laura.mesina@litere.unibuc.ro, https://orcid.org/0000-0003-0054-3788.

${ }^{1}$ Andrei Pippidi, Tradiţia bizantină în ţările române în secolele XVI-XVIII, Corint, București, 2001, p. 8-12.

${ }^{2}$ Ibidem, p. 22.
} 


\section{I.The Imaginary and the Imperial Image}

Imperial Byzantine $\operatorname{art}^{3}$ begins to reflect soon after 330, the year of the consecration of Constantinople, the new political theology of the image. Constantine places the effigy of Christ ${ }^{4}$ upon the central gate of the Imperial Palace, and above, the Byzantine cross; every coin issue confirms the endorsement of the lay power of the autocrat by the divinity ${ }^{5}$, through the juxtaposition of the figures of the two Joint Emperors of the Christian worlds, Jesus and the autocrat, the basileus.

During the transition from the political forms of the pre-Christian [Roman] Empire to the oikonomic organization of the Christian world ${ }^{6}$, the image of power will lose the notion of Aristotelian mimēsis (it will gain it, in a Neo-Platonist spirit, in the icon ${ }^{7}$ ), the realism of human countenance and the cult of physical beauty, exalted by Greek and Imperial Roman sculpture. I am here referring especially to the mosaics still indebted, in $6^{\text {th }}$ century, to Roman portraiture from the Justinian's basilicas Sant'Appollinare Nuovo, San Vitale and Sant'Appollinare in Classe from Ravenna ${ }^{8}$.

The connection with the aesthetics of the antiquity will not be regained until the end of the Italian Middle Ages, through the humanization of the faces in religious images. It will make progress at first timidly in the frescoes of Cimabue, later vigorously with Giotto and Simone Martini, and then, during two centuries, while traversing the entire Renaissance, it will reach the quasi-humanization of the Virgin in Michelangelo's Tondo Dodi or the physiological study of the characters of the apostles undertaken by Leonardo for his Il Cenacolo .

On the other hand, the Oriental part of the Christian Roman Empire,

\footnotetext{
${ }^{3}$ Louis Bréhier, La civilisation byzantine, $2^{\text {nd }}$ ed. Albin Michel, Paris, 1970; Talbot Rice, David, Byzantine Art, Penguin Books, Norwich, 1968.

${ }^{4}$ Gilbert Dagron, Naissance d'une capitale. Constantinople et ses institutions de 330 à 451, Presses Universitaires de France, Paris, 1974.

5 André Grabar, L'iconoclasme byzantine, Flammarion, Paris, 1984, trans. Daniel Barbu, Iconoclasmul bizantin, Meridiane, București, 1992.

${ }^{6}$ For the concept of the political oikonomia of Christianity, see: Marie-José Mondzain, Image, icône, économie. Les sources byzantines de l'imaginaire contemporain, Seuil, Paris, 1996.

${ }^{7}$ I am here referring to the documented work by Frédérick Tristan, Les premières images chrétiennes, Librairie Arthème Fayard, Paris, 1996, trans. Elena Buculei, Ana Boroş, Primele imagini creştine. De la simbol la icoană, secolele II-IV, Meridiane, București, 2002.

${ }^{8}$ Giorgio Ravegnani, La corte di Giustiniano, Jouvance, Roma, 1989.

${ }^{9}$ Umberto Eco, La definizione dell'arte. Dall'estetica medievale alle avanguardie, dall'opera aperta alla morte dell'arte, Garzanti, Roma, 1972; Idem, Arte e bellezza nell'estetica medievale, Bompiani, Milano, 1987, trans. Cezar Radu, Arta şi frumosul în estetica medievală, București, Meridiane, 1999.
} 
named by specialists' "Byzantine"10, in time separates itself completely from Ancient Greece artistically - although it also includes in the construction of the identity of Constantinople the philosophical and aesthetic Hellenic heritage ${ }^{11}$. This radical transformation was happened at level of conception of the image and imaginary of the body, integrated by the imperial ideology within the politics of its image ${ }^{12}$.

Before Constantinople saw the rise of the sacred statue of Constantine ${ }^{13}$ on top of the Porphyry Column - that real axis mundi proposed by "the second queen among cities" ${ }^{14}$ - "towards the end of the Roman Empire one could find in every one of its cities an icon, which irrefutably and officially incarnates a god: the statue of the emperor" ${ }^{15}$. Realistically executed, bearing the signs of his physical and facial identity, the statue functioned as idol and persona, in other words a substitute, an imaginarius; thus, it received honour in the place of the absent emperor. ${ }^{16}$

Having ideological roots in the imperial cult of Alexander the Great and stoic philosophy ${ }^{17}$, the Roman interpretation of Augustus ${ }^{18}$ manifests itself much more discreetly and prudently. As a pontifex maximus, a gobetween god and the empire, the emperor also acts as endorsement of the religious life. Victoria Augusta passed on as a warrantee of power on behalf

\footnotetext{
${ }^{10}$ In keeping with historical truth, the Christian empire founded by Constantine the Great, its capital on the ruins of the former pagan Byzantium, should rather be named "Constantinopolitan" (especially after the definitive establishment of the imperial residence in the Eastern Europe, by Constantine's son, Constantius II, at the expense of the Occidental capital of the time, Milan). Even if the syntagma "Byzantine Empire" has become a fixture of specialty literature and popular books, it does not represent a historical reality. For more arguments on this point, see Gilbert Dagron, op. cit.

${ }^{11}$ However, civic and popular religion and civic philosophy are not dogmatically confronted in the Greek world, but they undergo a transfer of concepts. Thus, philosophers often translate Zeus into their own conception of the divine in terms more pretentious. The Greek spirit, as well as its imaginary, is not separated from each other, despite differing visions or debates at one time or another, but they are complementarily built. See Besançon, Alain, "Critica filosofică a imaginii", in Alain Besançon, L'image interdite. Une histoire intellectuelle de l'iconoclasme, Libraire Arthème Fayard, Paris, 1994, trans. Mona Antohi, Imaginea interzisă. Istoria intelectuală a iconoclasmului de la Platon la Kandinsky, Humanitas, București, 1996, p. 19-72.

${ }^{12}$ Gilbert Dagron, Empereur et prêtre. Étude sur le "césaro-papisme" byzantin, Gallimard, Paris, 1996.

${ }^{13}$ Idem, Naissance and Empereur.

${ }^{14}$ Idem, Naissance.

${ }^{15}$ Alain Besançon, op. cit., p. 67.

${ }^{16}$ I would like to draw attention on the fact that the noun imaginarius, from the late imperial Latin, used to designate the one, which bore the face or the idol, the mask, or the statue of the emperor, as a sign of substitution, but also as a sign of the presence of the spirit of the one substituted.

${ }^{17}$ Gianfrancesco Zanetti, "Il pensiero politico di Aristotele", in Il pensiero politico dell'età antica e medioevale, UTET, Torino, 2000, ed. Carlo Dolcini, p. 64-68.

${ }^{18}$ Emanuele Narducci, "Il pensiero politico romano tra repubblica e impero", in Il pensiero politico dell'età antica e medioevale, UTET, Torino, 2000, ed. Carlo Dolcini, p. 99-121.
} 
of the divinity from one ruler to the other, also renders sacred his standard features, which entered already the religious vocabulary: pius, justus, clemens, pater patriae, felix ${ }^{19}$ (a mechanism for handing down power also taken over by the medieval "political" vocabulary).

However, the emperors after Augustus ${ }^{20}$ do no longer refine to such an extent the relative subordination to the divine, and push their personality cult until the emergence of an imperial theology, under the auspices of the sun $\operatorname{god}^{21}$

The imaginary of the imperial power receives, through the Roman exercise, a specific vocabulary, a military and civilian/civic ritual of the celebration of triumph, an ideology and scenographic paraphernalia ${ }^{22}$. These will spread thanks to the basileic institution through the entire history of the Christian Empire. Constantine himself is divus in an empire, which, by imposing the Christian religion as an official religion at an institutional level, immediately and very persuasively triggers a reduplication of the ancient political imaginary with an essential innovation. The mediation between the divine and the human is no longer located in the interaction between one idea and its image, as it was with Plato, or in the use of authority, or military force, as it was in Rome. Instead, it is the institutional person of the emperor himself, basileus, the terrestrial god delegated by the transcendental one ${ }^{23}$; "he is, according to the authors of panegyrics, the Platonic demiurge [the divine artisan] who enforces upon the world the laws he contemplates within the divine model ${ }^{24 \prime \prime}$.

His divine power coincides with the organizational structure of Christ's church, with his mystical body. The monotheistic logic of this project of linear history, whose telos is Salvation,

...keeps up with Plotin's theology: The One, the transcendental God, the Thinking, the mediating God, and the Soul, which spreads the divine at all levels of reality. It is also in keeping with the Origen's Christian theology and Eusebius of Caesarea: God the transcendental Father, the Logos that creates and leads the world through the Spirit. ${ }^{25}$

\footnotetext{
${ }^{19}$ Gabriella Piccini, I mille anni del Medioevo, Mondadori, Milano, 1999; Eugen Cizek, Mentalităţi şi instituţii romane, Globus, București, 1998.

${ }^{20}$ For a comment on the period, see Seneca, Lettere a Lucilio, Rizzoli, Milano, trans. G. Monti, 1985; Tacit, Tutte le opere, Sansoni, Milano, ed. E. Cetrangolo, 1993.

${ }^{21}$ Eugen Cizek, op. cit.; Gabriela Piccini, op. cit., p. 8-25.

${ }^{22}$ Eugen Cizek, op. cit.

${ }^{23}$ Gilbert Dagron, Empereur.

${ }^{24}$ Alain Besançon, op. cit., p. 69.

${ }^{25}$ Ibidem.
} 
After the imposition of the official religion, the consolidation of the state institutions through Constantius II ( $4^{\text {th }}$ century) and especially after the strengthening of church institutions under the imperial jurisdiction of Justinian (two centuries later), the imperium will no longer be distinguishable in Constantinople from the sacerdotium.

The slight Aryanism of Eusebius of Caesarea seems to have been the ideological impulse of this political vision, which influenced the first Christian emperor, created the framework for the imposition of his quasi-total power, helped him consecrate a religion whose purpose was the sanctification of the autocrat because "le pouvoir de fait ne devient pouvoir de droit qu'en se sacralisant ${ }^{26 \prime \prime}$.

The Christian Orient remains, through the theological force of its Orthodox dogma, faithful to the idea that each manifestation of the imperial power is a "theophany". This leads to political and implicitly religious schisms and to the fundamental mentality clash between Eastern and Western Europe with consequences for their civilization and imaginary.

The new imaginary of Christian power is no longer of an elitist philosophical nature, as the ancient Greek one, or of a military nature, as the Roman power. Its spiritualization combined the expectations of a popular religion disconcerted by the crises undergone by the Empire ${ }^{27}-$ due especially to the consolidation of the power of the Eastern provinces, most of them unofficially Christianized - and the authentic desire of the imperial institution to reform itself without any dislocations or military interventions. But this imposition - which in time turned out to work against Rome - had the main function of consolidating the concrete plan of the emperor and the Senate and of counteracting the desire for relative autonomy of the dioceses from the Eastern part of the Empire, especially those of Alexandria and Antioch.

At this point, I shall not dwell further on the importance of creating in Constantinople ${ }^{28}$ an alternative power and local administration. What actually lies within the scope of my paper is the emphasizing of the decisive translatio movement, for example undergone by Constantine's son, Constantius II. This emperor had the construction of Constantinople finished, instituted the sanctified image of the first Christian emperor of the Empire and decided that "the second Rome" should become the permanent residence and locus of supreme power for the entire Roman world ${ }^{29}$. It is in that time that the cult of Constantine ${ }^{30}$ originates, meaning his portrayal as the most important forerunner of any other Christian monarch as a true representative

\footnotetext{
${ }^{26}$ Gilbert Dagron, Empereur, p. 17.

${ }^{27}$ Gabriela Piccini, op. cit.

${ }^{28}$ Gilbert Dagron, Naissance and Empereur.

${ }^{29}$ Idem, Naissance.

${ }^{30}$ Ibidem.
} 
and executor of the divine will. This cult will continue thanks to the policy of the second founder of Christianity, Theodosius I.

From the end of the fourth century on ${ }^{31}$, the political imaginary identifies oneself with the religious one. More precisely, the first one appropriates the latter one and fundamentally modifies the society of the Empire in order to achieve their logical and persuasive combination. Constantine takes over the court ritual from Diocletian, adapts the imperial ideology ${ }^{32}$ and assimilates Byzantium's local deities into the famous cult of the sun and Christ's humane figure and he "doubles" the latter ${ }^{33}$, first as His own vicar, surrounded by celestial figures.

This policy of turning the autocrat into a sacred figure, especially relevant for the first Christian emperor, will eventually lead to the claim that this image can substitute even Christ's figure (as shown during the iconoclastic period). ${ }^{34}$

Constantine the Great builds upon the ruins of the Byzantium not only "the new Rome" - actually, the stronghold of the resistance of the Roman Empire in the Eastern Europe as the counter-candidate of Antioch and

${ }^{31}$ One should read Saint Augustine's work as a decisive move towards consecrating the beginning of the separation between the Eastern European Christian imaginary and the Western one; in this case, contemplation cannot simply find refuge in an inner world, by tearing itself free from the outside world. The human being needs to contemplate the divine work both in the real world and inside one's soul. Thus, Augustine, in his essentialist philosophy, divides the structure of the world not only around the idea of the One, but also that of the Trinity, of the transcendental relationships of divine entities with each other. However, this offers a dynamic character to his utopian imaginary from De Civitate Dei, as well as to each notion in itself, such as the image or time, and implicitly memory. Although postPlatonic, through his attempt of harmonizing the sensible with the intelligible, Augustine continues along the tracks traced by Aristotle by pinpointing the human will towards Form and Good. The ascendant path of this trajectory between matter and the divine can be found, with few variations, in the religious art from Assisi: "L'image n'est rien d'autre que la manière dont notre humanité est conservée en Dieu, ou, si l'on veut, elle est le seuil où l'authentique mémoire de soi se révèle être mémoire de Dieu. Le péché ne fait donc pas que brouiller en nous l'image de Dieu: il nous dissemblables à nous-mêmes puisque nous n'avons d'autre identité que celle de l'image. À l'invers, la grâce, en restaurant l'image, n'étire pas la condition humaine au-dessus d'elle-même, ou n'institue pas l'avénement d'une surnature. Elle ne fait que restituer l'homme à sa ressemblance filiale avec Dieu et à son identité originaire avec lui-même", in Lavaud, Laurent L'Image, Flammarion, Paris, 2000, p. 37. This vision allows the emergence of a religious image where the story and the humanity of the Christ are both accepted, and which leaves room for a kind of filiations, which allows for the inclusion within the image of the anonymous human figure next to Biblical characters. The philosophical dimension of time in Giotto's Franciscan frescoes from the Cappella degli Scrovegni in Padua or from the Assisian basilicas is of the most unadulterated Aristotelian and Augustinian inspiration.

${ }^{32}$ Hélène Ahrweiler, L'idéologie politique de l'empire byzantin, Presses Universitaires de France, Paris, 1975, trans. Cristina Jinga, Ideologia politică a imperiului bizantin, Corint, București, 2002.

${ }^{33}$ Gilbert Dagron, Empereur.

${ }^{34}$ Ibidem. 
Alexandria -, he does not only establish Byzantium as a sacred city through its "baptism" with a Christian name. He also consecrates the place where he sets up his headquarters as "universal Christian royalty" (at the expense of Rome, the first capital). The concept of "priest-king" founds on the Holy Book and the sonorous names of Old Testament beliefs. Oriental Christian Basiléia (the empire) and hiérosynè (sacerdocy) were incomparably more significant and politically dominant here, during that time, than in the Occident. Their association was based on ritual, on insignia of power, on the sacred "meeting" (from the entry into Santa Sophia, the ritual passed on into the post-Byzantine Orthodox world) of the autocrat with his highest priest (much like Moses and his brother, Aaron). Everything was in safe custody, though, according to perfectly established scenarios that had resisted the test of time. These scenarios became the treasure of the collective memory and imaginary, enriched with legends and images and turned thus into a source of permanent spectacle. Accordingly, the "consecration contract", the insoluble link between the protagonists and the public gained the status of norm and tradition.

After the iconoclastic period, Constantinople, marked as it was by the multiple crises, which contributed to defining its position as central headquarters of a Christian empire, finally opted for a "sacerdotal royalty". Gradually, close to the first Great Schism from 1054, Rome imposes, through the Catholic theology and the ideology of religious papal politics, a model opposite to the Orthodox Orient, "royal sacerdocy" ${ }^{35}$. The main causes of the rupture between pars occidentalis and pars orientalis, and of the consolidation of two types of culture and civilization so different - although both of them Christian - remain the confrontations between their political systems and theological dogmas. To put it differently, namely in the spirit of Gilbert Dagron's research, these two causes can be reduced to only one, since the lay power and the religious power were not separable during the Byzantine period and the medieval post-Byzantine period.

Unlike the other two religions of the Book, Judaism and Islam, whose message founds on a perfect synchronization between religious revelation and political organization to such an extent that any attempt to distinguish between the State and the Church becomes a non-sense ${ }^{36}$, Christianity has a different trajectory:

...c'est l'éclatement géographique du pouvoir romain qui favorisa l'éclosion d'une 'théorie des deux pouvoir', l'un temporel établi à Constantinople, l'autre spirituel demeuré à Rome; mais il suffit qu'une Eglise orientale s'organise autour de l'empereur et de son

\footnotetext{
${ }^{35}$ Jean Chélini, Histoire religieuse de l'occident médiéval, Hachette, Paris, 1991; Jacques Paul, L'Église et la culture en Occident, Presses Universitaires de France, Paris, 2 vols., 1994.

${ }^{36}$ Gilbert Durand, L'imaginaire, Hatier, Paris, 1994, trans. Anna Chiara Peduzzi, L'immaginario. Scienza e filosofia dell'immagine, RED, Como, 1996, p. 10.
} 
patriarche, ou que l'Empire ressuscite en Occident avec les Carolingiens et les Ottoniens, pour que le schéma se brouille et que cette théorie des deux pouvoirs se trouve confrontée à une autre théorie ou, pour mieux dire, à un autre modèle, celui d'une royauté terrestre conçue à l'image de la royauté divine, incarnée dans un souverain que Dieu a délégué directement au gouvernement et au salut des hommes, et qu'il a légitimé par l'onction ${ }^{37}$.

What it is here at issue is the fundamental question of Caesaropapism, within the vision of the Constantinopolitan world and the fact that the Oriental Church came into a conflict with the Occidental one - a defender of the "two power" theory - because it wished to maintain its dominance through a spiritual-religious pre-eminence.

On the one hand, the schisms are refuted by the Papacy precisely because of the Constantine's and Justinian's imperial interventionism (these are famous situations, to which one could add many others, especially those of the iconoclastic period ${ }^{38}$ ). On the other hand, the Occidental Church's own attempt to eradicate the involvement of lay power in the Church's affairs is neither as simple nor as clear as it claims to be.

Elle procède d'un amalgame et fait se superposer la distinction functionnelle entre les affaires de l'Eglise et les affaires de l'Etat, et la reconnaissance politique d'un pouvoir clérical indépendant d'un pouvoir laïc. Ici encore, l'Europe occidentale cherche à se démarquer de l'Orient et projette sur les écrits et l'époque du pape Gélase $\mathrm{I}^{\mathrm{er}}$ (492-496), promu théoricien, un augustinisme politique qui lui servit longtemps de doctrine dans un contexte de rupture historique et de fragmentation du pouvoir. ${ }^{39}$

This is one of the most powerful examples for what one could call "the influence of theory and the imaginary upon reality". The imperial political theory, despite modifications during the first Christian millennium, shall bring about, from Justinian's age on, a complete separation from the institutions of the Roman world. The closing of the philosophy School of Athens, during the $6^{\text {th }}$ century coincides with the fundamental modification of Roman Law, which becomes Byzantine law, and also, with the cancellation of the most important public decision-making structures taken over from Rome, the senate and the hippodrome ${ }^{40}$. Justinian's time represents the decisive and irreversible option for Orthodox Christianity; it is also at that point that what we now know as the medieval Christian imaginary is

\footnotetext{
${ }^{37}$ Gilbert Dagron, Empereur, p. 18.

${ }^{38}$ André Grabar, op. cit.

${ }^{39}$ Gilbert Dagron, op. cit., p. 27; see also p. 309-312 on the role of Pope Gelasio.

${ }^{40}$ Robert Browning, Justinian and Theodora, Praeger, New York, 1971, trans. Liliana Silvestri, Giustiniano e Teodora, Librex, Milano, 1974.
} 
consecrated and submitted to the European historical practice, and in time decisively altered by the multiple religious and political schisms, as far as 1054. Two kinds of political imaginary confront each other during the Crusades, but also two Christian Europe.

The separation of the Eastern world of the Constantinopolitan empire from its Western provinces, spiritually coordinated by the Papal vicarage from Rome, initially only a local delegation of the Oriental Patriarchal Church, originates in the $6-7^{\text {th }}$ centuries as a historical and spiritual process. The dispute around the image of Christ, first politically motivated ${ }^{41}$, closely follows the schism.

The seat of Byzantine power intermittently condemns and refuses religious images for two centuries (730-780 and 813-843 $3^{42}$ ) under the pretext of the competition with iconoclastic Islam:

La crise de l'iconoclasme à Byzance fut essentiellement une crise politique constantinopolitaine, c'est-à-dire une crise de ce qui fonde symboliquement l'autorité. La crise a concerné la conception même du pouvoir au niveau des instances hiérarchiques les plus élevées ${ }^{43}$.

The Iconodules, dogmatically represented by John of Damascus, were defending a theology of abstraction, which would thus reveal a world otherwise unavailable to the senses. The tradition is again that of Platonic idealism; the icon, whose prototype was the image of God incarnated in the person of his Son, Jesus, is actually a living image, projected and reproduced on the veil used by Saint Veronica to dry Christ's face during his martyrdom $^{44}$.

Thanks to the theological resistance of the Iconodules, emerges one of the most articulate rehabilitations of the image in the Christian Occident ${ }^{45}$

\footnotetext{
${ }^{41}$ Gilbert Dagron, Naissance and Empereur; André Grabar, op. cit.

${ }^{42}$ This moment was thoroughly analysed by specialists from a historical, political and dogmatic perspective. However, the icons were saved by monks or hidden by women in the gynaeceum. The need of representing Otherness and the apparent safety given by the image of a warranting divinity brought back Christ within the sacred space, through the dogmatic movement of the Iconodules and through the bravery of the feminine imperial power.

${ }^{43}$ Marie-José Mondzain, op. cit., p. 3.

${ }^{44}$ Ibidem, p. 217-275.

${ }^{45}$ The veneration of Christ as an embodiment of divine sacredness led to the veneration of other images of other sacred characters or incarnations (Théotokos, the Orant Virgin, Saint John the Baptist, the Crucifixion etc.). Veneration was already dogmatically prepared by previous centuries. See Frédérick Tristan, op. cit., p. 318-328, p. 331-339, p. 410-421. For the iconography of New and Old Testament narratives, see Ibidem, p. 145-299. Parallel to the strong iconoclastic rationalist current, Christianity sees the beginning of the era of the sacred image aesthetics, which Byzantine art will continue to refine a few centuries after the Great Schism. One sees various forms of idolatry, such as Mariolatry, the cult of relics, the pluralized cult of the virtue of divine sanctity, which will give in time a "polytheistic"
} 
directed against the ancient iconoclastic tradition and Hebraic monotheism, as well as the definitive consolidation of the structures of the Christian imaginary.

\section{II.The Political-religious Plan of Christian Oikonomia}

According to Marie-José Mondzain, this confrontation proved to be a dogmatic crisis of the concepts of the image and of oikonomia:

Il s'agit d'une conception économique de l'image naturelle fondatrice de l'image artificielle et d'une conception économique de l'image artificielle qui vient à son tour fonder le pouvoir temporel $^{46}$.

Situated at the conjunction of the invisible image of the divinity and its visible icon, oikonomia expresses their "living" articulation and the historical transfiguration of the eternal similitude (divine consubstantiation) through the phenomenon of temporal resemblance (Incarnation).

The doctrinal background of the iconoclastic crisis could not camouflage a twofold issue. On the one hand, it did indeed regard the relationship between the icon and the image of the Son, the concept of mimessis and the transfiguration of the Form. On the other hand, and seen from a political point of view, the issue belonged to the pedagogy of civic religion, and the strategy for maintaining the sacred basileic power (at the expense of the "terrestrial reign", through the image, of the Son) and the appropriation of the territory of faith.

The historical destiny of the artificial image has apparently hidden the problem of the natural image of Christ - which had become uncomfortable to the basileic institution - through its powerful dissemination in the Christian world.

Unlike some experts in Byzantine history who ${ }^{47}$ reduce the issue to a matter of power and institutional politics, Mondzain introduces, through the re-reading of Nicephorus, patriarch of Constantinople (758-829), the multiple issues at stake within the concept of oikonomia, which was finally to be systematized during the iconoclastic period.

Beyond the doctrinarian content imposed by the Apostle Paul, oikonomia refers to the dissemination of the image of the divinity through

character to religious observance, at least by comparison with the rigid monotheism derived from Hebraism. At the same time, they generate a plurality of themes and motives in religious art, image and, implicitly, the imaginary.

${ }^{46}$ Marie-José Mondzain, op. cit., p. 14.

${ }^{47}$ Hélène Ahrweiler, L'idéologie politique de l'empire byzantin, Presses Universitaires de France, Paris, 1975, trans. Cristina Jinga, Ideologia politică a imperiului bizantin, Corint, București, 2002, p. 121-139; André Grabar, op. cit.; Gibert Dagron, Naissance and Empereur. 
historical manifestations that provide visibility and accessibility to the human, to the evangelical discourse and the icon.

Finally,

[...] englobant dans leur totalité la stratégie et la tactique nécessaires à une gestion d'une situation historique réelle, l'économie n'a aucun mal à retrouver sa vocation classique : être le concept de la gestion et de l'administration des réalités temporelles, qu'elles soient spirituelles, intelectuelles ou matérielles $^{48}$.

Oikonomia is the manifestation of the divinity within history, but not only that. It is a way of distributing Christological truth and promise Salvation to the fallen humanity; it is also a way of displaying within the Christian space the exemplary model of the Saviour and his actions. However, in order to restore its multiple meanings, one should also add that it is the correspondent of administratio, applied to the distribution of ecclesia and its institution in the Christian world. The economy of symbolic religious goods of this world follows a divinely inspired plan, but only a certified institution may put it to practice.

During the iconoclastic crisis, the discourse about the image and the icon replaced the iconic image, precisely in order to defend and explain it. At least this is what emerges from Nicephorus's writings, which are much more virulent and pragmatic than those of John of Damascus and Theodore the Studite, both with a penchant for Christology and essentially doctrinal observations. According to Nicephorus, thought (Plato would have said "knowledge") and power (the analyses of the philosophical imaginary of the political realm become apparent here) are impossible without image, particularly without the divine icon.

Unlike Dagron, who sees in the comments on oikonomia mostly a clever rhetoric dominant within the doctrinarian debate of iconoclasm and a definitive disjunction between ideal norms and the social space, Mondzain proposes precisely the analysis of the imaginal and iconic device as a correlation between the spiritual and temporal power.

The basileic institution at the time - first a military one, and influenced by the iconoclasm of Oriental provinces and their armies, from whose ranks came the respective emperor-generals - declared against the use of the image of Christ and desired a different dissemination of the truth in order to favour its own image and way of running the Christian world.

The iconophilic discourse appeals through rhetoric to a ternary device: the sacred, nature, reason and these remind us precisely of the good, the existent and the thinking from the Platonic scheme. Rhetoric would thus be,

${ }^{48}$ Marie-José Mondzain, op. cit., p. 37. 
according to Mondzain, the science of effects in the most radical sense of the word, namely the demonstration through (the rational) logos of divine origin - as a manifestation of truth in life - of the oikonomic plan which reckons on the embodiment of the divine through word and icon.

The paradox of this crisis resides in the fact that it sets up a meetingplace between the Neo-Platonism of the Holy Fathers and the Aristotelian thought, which was already open to the possibility of the representation of the divine with a "paidetic" purpose. By inheriting the plan of Incarnation from the Apostle Paul, the patristic thought elaborates a Christian philosophy based on doctrine, which harmonizes the nature of the Son's image with the ecclesiastic project of transposing Christ's figure into the icon. This perspective produces the semantic organisation of oikonomic thought:

Il s'agit du premier concept organiciste et functionnaliste qui concerne simultanément la chair du corps, la chair du discours et la chair de l'image. Grâce à l'économie, c'est l'Église elle-même qui va être identifiée au corps du Christ, dont on doit pouvoir produire la visibilité afin que le royaume terrestre puisse se constituer à l'image du royaume céleste, dont il incarnera ici-bas la manifestation providentielle ${ }^{49}$.

One should also say at this point that, in a Christian society, one could not constitute legitimacy without a doctrine, which would facilitate recognition through the affiliation of the community with the institutional power structure. To believe and to obey become thus two walkways of the same symbolic path and in fact correspond to believe and to govern. The blueprint of Christian oikonomia functions finally "comme une gnose de l'énigme" ${ }^{\prime 50}$. What actually perfects the dogmatic and political definition of this concept is the mechanism of power, which makes the law, be adapted and enforced within the community:

Tout se passe comme si le long détour opéré par l'écriture néotestamentaire n'était là que pour prouver que Dieu a eu historiquement besoin du Fils, le Fils de l'Église, et l'Église du pouvoir temporel, toujours et partout, en fonction d'un même principe cohérent et logique : oikonomia ${ }^{51}$.

The organizational blueprint of the community in the city, reflected by the ancient political imaginary, helped later inspire ideas, which supported the institutional power for the administration of its own territory, either in the case of the Roman Empire or in the case of the Constantinopolitan one.

\footnotetext{
${ }^{49}$ Ibidem, 30.

${ }^{50}$ Ibidem.

${ }^{51}$ Ibidem, p. 31.
} 
Nevertheless, the Christian project turned out to be a much more precise application of Platonic theory: this project includes the theory of the divine, the functions of imagination, the triplet good, existent, thinking and the concept of "justice in the name of the good and absolute truth that is also the divine". In addition, the conjunction, through the Judea-Christian philosophy and the Epistles of Saint Paul, of the basileic political plan with the Aristotelian concept of oikonomia, led to the assimilation of this plan with the dissemination of the image of Christ in the nature of the Christian community.

It was the duty of the emperor of the Byzantine world - I am here again using the argument of the ancient political imaginary with Plato and Aristotle and the image of the philosopher-king or the wise leader - to provide for the management not only of the Christian world, but also of the plan of Incarnation. He was following a mixed tradition - both of the Old Testament and of Roman history - and inheriting the sacerdotal responsibility. This "combination of functions" was a matter, which brought together political and dogmatic arguments and led to the theory of the double nature of the emperor: he was genealogically descended from the emperor and the divine judge. Oikonomia was becoming a special inheritance, which only the "basileic autocrat" had the right to govern and run. The circle is closing: Plato's philosopher-king ${ }^{52}$, rendered similar to Christ by adding other features originating in mythological religion, might be nobody else but the basileic autocrat himself, who had a special knowledge of Christ's nature because he was himself a "delegate", "vicar" of God, or "anointed by God". It is precisely this concept, of the sacerdotal emperor, which lay at the root of the political-religious war between Constantinople and the Papacy (also mentioned in the present study) and even between the basileic institution and the iconodulic monastic institution during the iconoclastic crisis.

The two important conflicts under discussion, one of them resulting in the theory of Caesaropapism, and the other one in the political-religious theory of Christian oikonomia, lie at the root of the final split between the imperial institution and the papacy which came into existence already in the $8^{\text {th }}$ century. It led also to the formulation of two types of political-Christian theories of power and to the re-evaluation of "sacerdotal royalty", which transforms the relationship emperor-patriarch and formalizes the anointment ritual. Implicitly, two imaginaries are going to become separate starting approximately from the same century. Constantinopolitan basileia finally becomes a twofold power, lay and religious, an absolute warrantor of both the economy of the terrestrial world and the oikonomia of Incarnation.

Mutatis mutandis, the despoteia ${ }^{53}$ of the Romanians results from this

\footnotetext{
${ }^{52}$ Also see Céline Spector, Le pouvoir, Flammarion, Paris, 1997, p. 41-52, p. 77-99, p. 115 116, and p. 157-159.

${ }^{53}$ Daniel Barbu, Byzance, Rome et les Roumains. Essais sur la production politique de la foi
} 
line of the political imaginary of the Orthodox power, although following some important, specific, transformations.

\section{III.The Model of the Medieval (Romanian) Imaginary and the Heritage of the Ancient World}

The first part of this study of the pre-modern Orthodox political imaginary represents a selective thematic approach. The scientific purpose has been to configure the relationship between my former comments on the ancient political imaginary and on the image ${ }^{54}$ and the project of the imperial, Christian and oikonomic, power, of governing with the help of the image.

I would also like to add the following two remarks to the theoretical explanations from the first part:

1. I introduced, as fundamental elements, the results of the research undertaken by Marie-José Mondzain ${ }^{55}$ on the concept of Christian oikonomia. I think her research supports and strengthens the perspective on the medieval imaginary model, which I propose in the present study. The plan of disseminating the Christian basileic power and the ecclesiastic institutions, together with the idea of an incarnated Christ, through the Eucharist, in every Christian, but also the oikonomia of the "artificial" image, the icon, have all become determining factors in the set up of the medieval imaginary ${ }^{56}$. More than a political theory, more than a theological or dogmatic philosophy, the meeting between the discourses mentioned above has triggered the formation of a coherent plan for practical management not only of terrestrial goods or symbolic power, but also of the Christian community as such. This plan had to relate to the general pedagogical one, in keeping it up with Christian morality and Christian basileic politics. What passed over from the Byzantium to the Romanian Principalities was not an entire basileic system of government, but, as I shall be trying to show, the plan of the organization of oikonomia ${ }^{57}$ and its image, reflected in the medieval Romanian imaginary.

2. When analyzing the semantic and conceptual field of the term

\footnotetext{
au Moyen Âge, Babel, București, 1998, p. 123-143.

${ }^{54}$ I consider the image - as well as the symbol and the sign - to be a minimal functional unit in the imaginary system. See Laura Mesina, "Imaginarul ca formă de 'narare' a istoriei. Propunerea unui model cibernetic", in Analele Universităţii Bucureşti, XLXX, 2001, Editura Universităţii din București, București, p. 49-60.

${ }^{55}$ Marie-José Mondzain, op. cit.

${ }^{56}$ Daniel Barbu, op. cit., p. 13-17.

${ }^{57}$ Violeta Barbu, "Lex animata et le remploi des corps", in L'empereur hagiographe. Culte des saints et monarchie byzantine et post-byzantine, New Europe College, București, ed. Petre Guran, 2001, p. 232-238.
} 
oikonomia, Mondzain analyses the emergence of the notion somehow closer to the modern understanding of the term ("economy") - in the philosophy of Aristotle and that of the Sophists. We might correlate the latter perspective on the way justice and the law founded in the ancient city with the pragmatic understanding of the Stagirite: irrespective of the context and various other shades of meaning, oikonomia implied for the Greeks the organic finality and functional harmony, which led to social unity and political performance. The administration of private life related to the more general matter of the government of public goods and services and the ratio between "profit" and utility. Plato rejects this pragmatic perspective. His idea of "public service" had nothing in common with utilitarian gain or motivation. The leadership status of the philosopher-king was bereft of the advantage of wealth from which the aristoi of the Sophistic democracy benefited.

Still, oikonomic administration in the ancient society did need human intervention, even with Plato, in order to reach a perfect organization. In Christianity, this became the meeting-point between Aristotle and Plato's view of the term, which led to the assimilation of the term within the imperial government project, through its interpretation by basileic theocracy.

In relation to this issue, Mondzain later dwells on the way the Holy Fathers sensed the fundamental connection between the destiny of the artificial image (the icon), the "transfigured flesh" of the natural and invisible image (the divinity) and Christian reality, vivid and bodily, of mortal and political human beings. Oikonomia attempted, from a theological point of view, to underline the relationship between the theological imaginary and human existence, as well as the destiny of the truth of Incarnation, especially when early Christianity needed to act efficiently against any form of idolatry. Moreover, Oikonomia led to the conjunction between: a. temporality, as an immanent historical manifestation of the eternal and transcendental divine model, with Trinitarian philosophy ${ }^{58}$ and Christology ${ }^{59}$; b. the religious discourse (text and icon) ${ }^{60}$, pedagogy ${ }^{61}$ and the running of daily administration $^{62}$.

The transfer of concepts from Greek thought and the ancient political imaginary to the Christian imaginary proved important, but insufficient. The organization of the world dominated by a city-state or a capital-state could no longer merely focus on the concepts of civic harmony and public utility. The

\footnotetext{
${ }^{58}$ Marie-José Mondzain, op. cit., p. 44.

${ }^{59}$ Ibidem, p. 48.

${ }^{60}$ Ibidem, 64.

${ }^{61}$ Ibidem, 78.

${ }^{62}$ Ibidem, 83.
} 
philosophy of pre-Christian power had a decisive meeting with the new theological philosophy, which could not possibly fully assimilate the rational Greek-Roman plan for civilizing the world and the military approach of Roman troops. The new persuasive idea of spiritual unification - the filial image - would resolve, albeit not without resistance, the religious and political crises, which Constantine's empire was inheriting. Thus, Christianity emerges as a spiritual-religious solution to the management of power and of social forces, and to the social, cultural and political unification around the idea of Salvation.

The imperial institution takes over this topic and appropriates the idea of oikonomia, thus devising a twofold plan. On the one hand, it regards the administration of the symbolic goods of Christian spirituality, but, on the other hand, it focuses on the organization of the life of a community which is waiting for Judgment Day (and implicitly, watches this waiting and all its Gnostic or heretic diversions). However, at some point "the imaginary of waiting" combines with that of "the next world", borrows, among other things, the popular Christian representations of the devil and greatly refines the complex matter of punishment and atonement. Was it not that, apart from the institution of basileic power, the clerical institution and the powerful, elitist and vehement monastic institution from the Byzantine Orient ${ }^{63}$ wanted also to join the "deputy government" for the enactment of oikonomic politics? We commonly identify this as the main cause of the disruptions within the interior policies of the Empire in whose wake the Romanians also chose to take place in the fourteenth century.

\section{III.1. A Model of the (Romanian) Medieval Imaginary}

By the model of the medieval imaginary, I understand a means of organizing the power relations between public and private space, main agent of power and marginal elements of society, autocrat and subject, our world and transcendental world, as well as between the lay, the religious and the heretic. This system is like a graphic network through which I am attempting to represent a systematization of collective ideas by a community. At the same time, I am going to show that there is a multiplicity of common denominators, especially in the rationalization of the model, between the ancient political imaginary and that of the Christian power.

The structures of this imaginary, identified on the basis of "literary" and "non-literary" historiography, iconographic programs, religious art and mentalities that can be deducted from official documents, are organized like a matrix, according to three dominant dimensions (which I shall call "registers") of the spiritual and perceptible "space": lay, positive religious

\footnotetext{
${ }^{63}$ Daniel Barbu, op. cit., p. 25-48 and p. 49-60.
} 
(the divine) and negative religious (the demonic).

These three parallel lines intersect four levels (specific to the premodern imaginary) and show unities which we could group two by two:

A. typological levels (1-2) - the imaginary of power (male) and the imaginary of everyday life (marked by the - silent - presence of marginal groups);

B. functional levels (3-4) - the "chronotopic" imaginary (space and time, symbolically employed) and the "generic" imaginary (of "literary" creations, such as popular novels or high cultural texts, such as Istoria Ieroglifică and Tiganiada ${ }^{64}$, both baroque, but still representative of the medieval imaginary).

Thus, I am conventionally identifying twelve "zones"/modules (which result from the form of the matrix), with their own spatial-temporal identity, but also with a powerful socio-political and/or dogmatic identity. The levels and registers are the "fixed" areas of an ensemble which I am representing tridimensionally, in order to offer (and acknowledge) enough space for the manifestation (and the coalescence) of all the sub-relationships which may be established between the visible and generative structures of the model.

I am also proposing a slight modification of the famous dichotomy established by Mircea Eliade between the "sacred" and the "profane" ${ }^{\prime 65}$. In the middle ages, the lay space is practically invaded, in the spirit of the oikonomia of the image and Christ's example, by the presence of the sacred, of the Canon (be it alimentary, moral, pedagogical, or sexual) and of icons in the private space.

In this case, the abovementioned distinction could be re-evaluated. Since all the spaces of the Christian world are under surveillance, through various methods, by the Christian dogma and morality, both warranted by the lay power of the autocrat, one could also use, beside the famous dichotomy "sacred space-profane space", other distinctions between "private space" and "public space", or between lay space and the religious one. By the last one, I am referring only to the area usually inhabited by clerics, ascetics or saints, where religious ceremonies and canonized Christian deeds take place.

In addition, since opposition to the Canon indicates the space of the demoniacal, we could consider the latter to belong also to the realm of the

\footnotetext{
${ }^{64} \mathrm{I}$ am here including this work in the very short list of purely literary pre-modern Romanian writings, although it is illuminist through its ironic and baroque spirit and through its natural inclusion in the emancipation of the $18^{\text {th }}$ century. Still, I believe that the narrative substance of the epic poem is medieval, even if the vision of the author is illuminist. I am hereby including it as a "witness" in this list, as a reflection - parodic, as it may be, and perhaps even more so of certain medieval topoï (of a historical, political, legendary, symbolic, social and cultural nature) of the imaginary. See also Nicolae Manolescu, Istoria critică a literaturii române, vol. I, Minerva, București, 1990, p. 135-148.

${ }^{65}$ Mircea Eliade, Le sacré et le profane, Gallimard, Paris, 1965, trans. Rodica Chira, Sacrul şi profanul, Humanitas, București, 1992.
} 
religious, but in a negative way, in order to underline its radical difference. After all, we cannot rule it out from dogmatic thought. Finally, we obtain the following categories: the public-private (the imaginary of power - the everyday imaginary, i.e. the first two horizontal typological levels), the lay (marked by the sacred), the divine religious and the demonic religious (the three vertical dimensions).

Within the unit obtained by the intersection of the imaginary of power with the negative (demonic) religious imaginary, I shall introduce genres as moralizing stories, hagiographies, popular books or "princes' mirrors" (punishment is generally presented as an effect of Christian morality, and not of political justice or law).

1. The first typological level is that of the codes and roles played by the male element in the lay space, in the positive (divine) religious and the negative (demonic) religious one. In the public space, power is thus manifested:

a. In the lay space:

- Through a "heroic code" - the model of the forerunner, of the autocratic crusader, the knight, the roles within the relation of faithfulness (for instance the relation between master and subject in order to avoid the term "vassalage" which applies to another historical-political reality and another system of symbols ${ }^{66}$ );

- Through a "cultural code" which manifested itself through actions of building, financial support, printing etc., or during ceremonies and rituals - the model of the learned Christian autocrat, the model of the builder.

b. Through the intersection with the positive (divine) religious, the following models are produced: the model of the divinity, the model of the apologist, the ecumenical model, the ascetic, clerical or monastic model (for the cultural code), the model of the liberating saints, the martyr saints (for the heroic code);

c. These find their opposing factors within the negative (demonic) register: the anti-model of the Christian traitor or the heretic (a ruler, boyar or warrior) and the anti-model of the pagan, included in the iconographic programs in the devilish anti-model, the opposing term for canonical religious models.

2. On the second level of everyday life (also typological, as the first), the presence of women, who come out of marginal groups, indirectly stamp their personality overall structure.

The most important moments of life - birth, marriage, death -, the sin and

\footnotetext{
${ }^{66}$ Jacques Le Goff, "Ritualul simbolic al vasalităţii", in Jacques Le Goff, Pour un autre Moyen $\hat{A} g$ e, Gallimard, Paris, 1978, trans. Maria Carpov, Pentru un alt ev mediu. Valori umaniste $\hat{n}$ cultura şi civilizaţia evului mediu, Meridiane, București, 2 vols, 1986, vol. 2, p. 175-254.
} 
penitence $^{67}$, the dress, food, pedagogical and sexual codes all depend upon the relation between the feminine and the masculine and the legal codes (laws imbued with the sexist religious canon) and an intrusion of the dogma within the private space. The public eye (of power) carefully monitors the presence of women in the public space; anyway, it is limited and stereotypical.

a. The roles of the woman (extremely scarce in the medieval Romanian text) are the mother, the wife (seldom) and the daughter of the autocrat, the woman belonging to the court entourage, the ordinary woman. These models of the lay space find their counterpart in b. and c.;

b. In the positive religious model: the model of the Virgin, Saint Helen, the female saints (from hagiographic texts);

c. In the negative religious, register Eve, the witch, the adulterer, the female sinner etc. an abstract

3. The chronotopic imaginary, situated on the first functional level can be subdivided from a temporal point of view according to the subject:

a. Historical, social, cultural, political, private, the time of - for the lay register;

b. Liturgical, biblical, evangelical, apocalyptic, hagiographic - for the positive religious register;

c. Biblical, evangelical, apocalyptic, hagiographic - for the negative religious register

Space can also be thus structured, function of its nature (closed, open and transitional/connective):

a. House/city/palace, inn/village, park/garden and forest/jail, as a transitional space: door/attic, road, territory, porch/pavilion/square etc;

b. Church/cell/cave, heaven, porch/door/church vestibule, desert, terrestrial space etc;

c. Hell, forest, city/village, terrestrial space, desert, crossroads etc

4. The fourth level, a functional, but also a "generative" one yields the literary genres that are specific to narrative structures not pertaining to historiography (popular books, political fables etc.). In these texts, one can find the majority of the units of the superior levels. All these works are a fundamental source of the collective imaginary. From the point of view of their value and expressiveness, they are a summum of the medieval Romanian imagination. Consequently, their placement under level four does not imply any sort of inferiority by comparison with the typological or chronotopic level. I have located them in an individualized "space" because of the exceptional relevance that they

${ }^{67}$ The imaginary of death is dissembled in the general medieval model, in the vertical antireligious register, in the pattern of roles and mostly at the level of the chrono-topic imaginary. 
have within the entire network.

The "artistic" value appears in a few texts of incontestably literary nature (such as popular adventure books, Vieţile Svinţilor and Psaltire pre versuri tocmite, Istoria ieroglifică and Ţiganiada, translations from the Holy Books and hagiographies) or bearing the marks of "literariness" (horoscopes, zodiacs etc.). Nevertheless, it also appears in iconographic programs - whose authors (i.e. those who reflected on the philosophy of their images) we are not able to identify in an unquestionably way - and further in remains of religious art in general. The present study does not focus on literary value, be it deliberately sought or involuntarily obtained and does not attempt to establish an axiology of these witnesses of the medieval Romanian identity. What are important for me are that all these categories - allegory, metaphor, euphemism, symbol, the marvellous, the miraculous, the magical, the fantastic and demonic bestiaries etc. as well as types, models and chronotopoï - relate one to another in so many ways that they produce the very substance of the medieval Romanian imaginary.

In order to finish the description of the model I have proposed I should first re-discuss the concept of "representation". This can be functional both within the imaginary and as an independent unit, without the symbolization process Le Goff ${ }^{68}$ claimed to be necessary. The first two levels comprise mostly the socio-political, cultural and spiritual-religious roles (models, types and sub-types). I shall name them social representations of the characters (in the historiographical narratives or in the general body of texts whose ideas can sustain the model of the imaginary).

Certainly, they all gain symbolic value at some point as founders, crusaders, traitors, perjurers, mothers of autocrats, their daughters etc. Still, since the model proposed here has also a powerful socio-political character, I must emphasize the real identity of the individuals before they become symbolic for the community's imaginary.

The symbolic, discussed by Le Goff ${ }^{69}$, enters the model of the imaginary with the entire scenographic arsenal of lay, divine or demonic power, and its specific typologies: symbolic chronotopoï, ritual codes, scenographic inventories, bestiaries, systems of specific values, "complexes" of power. The symbols constitute the substance of the medieval imaginary due especially to their conventional nature: the capacity of correlating the perceptible or non-perceptible (the imagined) with the religious. We can remark the ambition of the medieval Romanian power structures to organize their own world according to a Christian oikonomic plan, as well as the often

\footnotetext{
${ }^{68}$ Idem, L'imaginaire médiéval, Gallimard, Paris, 1985, trans. Marina Rădulescu, Imaginarul medieval, Meridiane, București, 1991, p. 6.

${ }^{69}$ Ibidem, p. 7.
} 
harsh and demanding historical realities. The major connotation of the imaginary through symbols demonstrates the deep political desire of the community to construct a viable, moral and well-structured self-image, in order to ensure its own mechanisms of social purification and elevation. Thus, the model finds its counterpart in the anti-model in order to enhance its exemplarity and persuasive force.

The mechanism behind the construction of this matrix of the imaginary makes use of the anthropological factor (the differentiation between the masculine and the feminine), as well as of the vision specific to the anthropology of power (master-subject, laic power-religious power, public power-private power). The four vertical lines of my model cross the three qualitatively differentiated levels following a personal interpretation of the Durandian $^{70}$ model of space, completed by Zumthor's perspective ${ }^{71}$ and the view of Le Goff ${ }^{72}$ on temporality.

On every horizontal level, three modules emerge. The first one corresponds to the lay world, the second one refers to the exemplarity of the church and its theological or hagiographic models, and the third module is given by counter-examples - this, in a ternary rhythm where the included third term represents the generative and corrective force of the divinity (see the previously discussed Platonic scheme).

In this way, the three vertical registers find their correspondent in the threefold scheme of the imagination. The results are the plan of the perceptible - the icastic imagination (according to Plato's concept of eikasia), the plan of the divine - the iconic imagination, which translates the non-fantastic non-perceptible (the very substance of dogmatic polemics, of iconoclasm) and the plan of a-logical non-perceptible - fantasy (the art of combinations, hybrid, the demonic, the "next world").

The differences between imagination and fantasy are thus beginning to function within the model, with the semantic functions established by the European tradition ${ }^{73}$. Fantasy operates upon the corpus of fantastic, fabulous images, around the demonic complex or in "non-icastic" cultured literature, while the imagination is rather limited to the representation of lay or religious norms (i.e. historiography, church regulations, and Christian moral).

By following this scientific way, one can achieve the connection between the anthropological view of power and the structural principles of the registers, modules and the (theoretical) system of the medieval imaginary, which I have dealt with in other studies ${ }^{74}$. The model I am proposing here

\footnotetext{
${ }^{70}$ Gilbert Durand, Les structures anthropologiques de l'imaginaire, Dunod, Paris, 1992, trans. Marcel Aderca, Structurile antropologice ale imaginarului. Introducere în arhetipologia generală, Univers Enciclopedic, București, 1998.

${ }^{71}$ Paul Zumthor, La mesure du monde, Seuil, Paris, 1993.

${ }^{72}$ Jacques Le Goff, op. cit.

${ }^{73}$ Maurizio Ferraris, L'immaginazione, Il Mulino, Bologna, 1996.

${ }^{74}$ Laura Mesina, art. cit.
} 
takes into account an anthropological approach to power relations in society. These relations are further dealt with by superposing the third vertical register (i.e. the negative religious), of the system of punishment (programmed either within the human system of punishment or within the Divine one, i.e. within the "space" of the next world, especially hell).

Unlike the conceptual system of the imaginary ${ }^{75}$, where the archetype appears on a first (horizontal) paradigmatic level, it does no longer occupy a specific "location" within the model of the medieval imaginary. On the contrary, It disseminates among the modules of the second vertical register, placed under the positive sign of the religious (like an included triad) and takes the shape of individualized faces (evangelical faces, martyr saints, soldier saints, feminine figures which are seen as sacred); these function pedagogically, in the spirit of Christian morality, as models, types and subtypes. It also relates to the first module of the system, that of the lay autocratic power.

Those elements that give the shape of a theoretical system provide the substance of the medieval imaginary model. The same goes for the "semiotic system of power" (thus named by Le Goff ${ }^{76}$ ), respectively the crowning ritual, the stage codes and other ritualistic scripts (such as, in medieval Romanian historiography, the reception of ambassadors, the banishment, the welcoming of the prince on the border etc.). These formulas, descriptions, or narrative sub-structures occur in the space between the levels, upon specific discursive trajectories, configured either in texts or in images.

This is why I have been insisting on the fact that public discourse (I am here referring to what has reached us as a witness of the past) is a model for the imagination process, for the establishment of the structured "organism" of the imaginary. The mechanisms of narration and common (collective) mentalities function in this well-structured model of the imaginary with their own identity. As the space of the real world is under the sign of masculinity, the imaginary, on the first level, contains also masculine models, through the political-historical and spiritual-religious exercise (or through the aforementioned corresponding anti-models). The same lay space individualizes a specific space for marginal groups (the house, the yard, the hidden rooms, the adjacent road etc.); consequently, the imaginary also individualizes "the everyday" and various chronotopoi, by respecting different hierarchies of the real world.

What the imaginary has in common with narration is the theatricality of spaces and the identification and individualization of specific moments (dinner time, the time for work, rest, war; the time for mass and the time for death, the "time" of the next world; the time for working in the field or the time for travel etc.). In addition, the characters and their roles, establishing

\footnotetext{
${ }^{75}$ Ibidem.

${ }^{76}$ Jacques Le Goff, op. cit., p. 457.
} 
power relations, the teleology of those actions and laws, regulate the respective mechanism. It contains narratives, which follow the tridimensionality of the system and, by relying on mnemotechnic structures or narrative strategies particular to those times, and perspectives, produce a number of exemplary tales, behavioural patterns, novels and adventure stories. These structures fire up the imagination and build a "therapeutic" space of imaginary escape (in spite of its control by the policies of translating, printing and disseminating the book) from dogmatic pressures and confining exemplarity.

These are other examples of the manner in which reality and the imaginary "collaborate" and trace similar trajectories and strategies because, since they are permanently related and keep transferring information from one area to the other, they need to have common encoding and decoding mechanisms that are easy to understand and utilize by community agents.

The conceptual system of the imaginary, which I have dealt with in another study (quoted above), can thus be found in the whole model which I am proposing for the Middle Ages, which emerges everywhere in Christian culture and popular imaginary. It is very common, indeed, this complex mixture of archetypes, official religion, popular beliefs, heresies or gnosis, with its specific bestiaries, complexes, codes and chronotopoi and areas where the "imagined imaginary" is generated by a (pseudo-) scientific frenzy, but which in the end manage to articulate a "literary area". It is precisely this special function of the medieval process of imagination, fantasy, which "closes" the system on two sides:

- A vertical one (the third register, that of anti-models, but also of the "next world" and the demonic);

- A horizontal one (the fourth level), the one which was previously identified as belonging to literature, in the true sense of the word

\section{III.2. The Ancient Inheritance at the Level of the Collective Imaginary}

Following an analysis of genealogical archaeology (such as the one undertaken in the first part of the present study), I can identify the following characteristics of the medieval imaginary:

1. Unlike the irreconcilable distance between knowledge and opinion in the philosophical imaginary of the political in Plato's work, the medieval imaginary functions at their intersection point, because, in the Christian dogma, the knowledge of truth actually meant becoming closer to the divine by integrating the self in the collective project of Salvation.

2. After having distinguished their meanings during the Middle Age, the imagination and the fantasy shared and individualized later on the field 
of the imaginary. Fantasy went more in the direction set up by Plato as "inferior" to the imagination, an intellectual function that will later be given more credit (see the semantic and conceptual dimensions of icasticity and iconicity). Fantasy remained characteristic of the popular Christian imaginary and the cultured non-canonical one.

3. If we keep to the medieval meaning of the word phantasia ${ }^{77}$, then once again we meet Plato halfway: in his philosophical comments on politics, the good appeared as a substitute for the divine and opposed, as a supreme truth, the fantasy (although he himself, as an author, often used the imaginative function). Almost in the same way, the medieval imaginary distinguishes between, on the one hand, the product of the icastic imagination and the iconic one, understood as an irrefutable truth - the image of the divine or the real model - and, on the other hand, the product of fantasy, the non-truth, the non-divinity, or, more precisely, the (imaginative) image of the devil.

4. The relation between the art of leading the city-state - politeia - and justice integrates into the model of the medieval imaginary. Models of leaders, founders, monarchs etc. who build "the princes' mirrors" and the whole exemplarity prescribed by historiography attests the obsession of power of presenting itself as the only and the worthiest agent for fulfilling the destiny of the community, thanks to a perfect government in a perfect state. The same relationship as in Plato's work between the ideal model and the real city is maintained in official medieval culture, and projected upon the imaginary, through iconographic programs or texts containing analogies between the holy cities of Christendom and the spaces of the concrete (Romanian) world. Moreover, these symbolic models must protect, influence and guarantee, as much as possible, the wise governance of local princes. The rationalization of power through logos surfaced in Plato's work as the ideal model of the city; in the same manner, the medieval imaginary contains the symbolization of Constantinople as a lost ideal image. The difference lies in the fact that Plato's philosophy projects the ideal into the future, whereas medieval thought seeks supreme consecration in the past.

5. As to the overlapping of systemic representations which can be identified in the ancient philosophical imaginary of the political and

\footnotetext{
${ }^{77}$ Latinist medievalists see phantasia as a negative element, vana phantasia, not unlike sleep, phantasia somnialis, or, even more than that, as phantasia diabolica, whereas the "imagination" is attributed more to the body and its problems with the object world. Basically, starting with the Latin translation of Aristotle's texts, in the $12^{\text {th }}$ century, there is a difference even for the same graphic form of the word "phantasy". The noun has the following two meanings: the translation from the Greek philosophical text means "the reproductive faculty of the spirit", while the transliterated term from the Greek into Latin and attested from the time of Pliny the Old signifies a faculty of spiritual reassembly and invention.
} 
that of Christian power: the triad good - existent-thinking from Plato resembles, in the Christian vision, the relationship divinityIncarnation-revelation (fundamental for the political-oikonomic plan) and, in the vocabulary of power, the relationship inspired power (of the autocrat)-perceptible-imaginary. These identifications, together with that of the generative included third term (the good, the Christian divine and the divinely inspired power of the autocrat) and the dualities of ideates constructions (concrete-abstract, temporary-non-temporary, limited-limitless) bridge the gaps between the ancient philosophical imaginary of the political and the Christian one.

During the middle age, the symbolic power becomes a summum of this double conversion. One should emphasize the fact that Plato never reconciles knowledge and faith: these sets up the difference in terminology and in the relationship between truth and sensation, imagination and image in the two aforementioned systems.

6. Knowledge guarantees the supremacy of justice in the ideal Platonic model and the only one who can hold it is the philosopher. Through a transfer of meaning, Christ, the embodied Logos himself, is the one who appears in early Christian iconography as a young philosopher, Apollo or Helios. Since basileic philosophy will use the identification of Constantine the Great with Sol invictus, the closeness between the emperor and the Christ figure will be more or less subtle. In any case, Jesus is the first who embodies the supremacy of the philosopher in Plato's triad, then the emperor, the only one who is licensed to fulfil the project of Christian oikonomia on earth. The Romanian princes will take over this model later.

7. The usurpation of the Christic icon and its prestige in the spiritualreligious oikonomia only led to the failure of iconoclastic emperors. In consequence, the Christian imaginary was institutionalized, from the $8^{\text {th }}$ century onwards, not around the person of the emperor (an imperfect Caesar), but on the administration of power on earth and the reflection of this imperial plan. Since the image of the basileic institution suffered, Plato's triad developed as a political response (also including the political tradition of Latin-German empires), and it was finally fulfilled, towards the end of the first millennium, by the medieval scheme (identified by Duby after Dumézil's model): "the clergy, the aristocracy and the lower classes" (oratores, bellatores, laboratores). In the Romanian Principalities, we can only see a real political configuration of this triad of power in the $17^{\text {th }}$ century, after the decline of the centralizing system of the Voivod.

8. In all the political spaces where the two states manifested themselves, there is often a covert struggle for the main part in the practice and administration of the oikonomic plan. Still, irrespective of the result of 
this confrontation in the Orthodox Orient or the Catholic Occident, political art is an overwhelming art of the royalty (as in Plato's work), and its practice always results in the perfect architecture of the world (and its imaginary).

9. The Christian political vocabulary theorizes and includes the civic virtues proposed by the program of the first civic society imagined in Politeia (The Republic); moreover, these virtues help configure models and types in the medieval imaginary: wisdom, temperance, the sense of justice and courage all characterize the representative figures of power.

10. In order to strengthen the force of these models, the medieval imaginary also includes, as I was saying earlier, as a corrective "measure", the image of the "next world", divided into heaven and hell. The promise of the immortality of virtuous souls, which Plato had also projected, but in the pre-Christian imaginary, in a location more beautiful than that of the terrestrial space, comes back in the Christian imaginary and becomes a remarkably particularized place, present both in texts and in religious iconography (the latter being much more persuasive, especially in oral cultures). What is interesting is that the promise allows free will to manifest itself: both in the work of the Greek philosopher and in Christian dogma, it is not the gods who decide, but the human being, who has the capacity of choice. Unlike the ancient man, who could only choose the right path with the assistance of philosophical practice and the access to divine knowledge (i.e. the good and the bad, hence also the divine), for the Christian the otherworldly forgiveness and happiness can only be obtained through faith (an essential element for the difference between the two periods).

11. The four characteristics of the perfect ancient state - it is immobile, artificially instituted, and authoritarian and accepts only divine truth can be fully found in a Christian imperium. This is precisely why I was saying, when I was referring to the philosophical imaginary of the political in Plato, that the theory of the Greek philosopher did not apply during the antiquity, but that, thanks the conjunction between the Neo-Platonic thought of Judaeo-Christians and the Roman political structure, it reached a workable translation, close enough to the theory. In the case of the Stagirite, there are fewer common points between his political theory and the actual substance of the Constantinopolitan Christian perspective on the exercise of power. First, in his case, political knowledge underlines the differences within humanity. In order to have individual relevance, political action is only viable if it works in the spirit of "the good life" for each individual of the city.

1. One of the ethical explanations for the difference between the system of political organization of the Eastern Christian Empire and the multiple systems of Western organization (perhaps starting with the 
$13^{\text {th }}$ Italian century), could reside in the view on happiness as honour and fame. While the dogmatic distinction between Orthodoxy and Catholicism became clearer, the focus was also sharper put in the East (Plato's vision) on the duty to the basileic institution, the ecclesia and the divine power.

Another explanation might be the distribution of power in the two spiritual European areas: the unique position of the basileic emperor completely undermines the free will of his subjects. These were not allowed to choose their master, as the code of vassalage would later stipulate in the Occident.

Here may be located an essential feature of the rupture between the two types of systems of power during the middle ages.

In addition, the social nature of the ethics of happiness finds spiritual fulfilment in the $13^{\text {th }}$ Italian century through the contribution of Franciscans to the formation of the social ethics of the pre-Renaissance city. On the contrary, the Orthodox Orient pulls back the concept of philia into the clerical environment and adapts it to monastic life. Political thought does no longer include the ethical dimension of friendship as a dominant of the system of power relations. Thus, the Orthodox medieval imaginary no longer reflects the Aristotelian politiké philia.

2. The Aristotelian concept of justice did not apply in the legal practice of the Eastern Europe. Rather, one can find here Plato's perspective on justice, determined by the metaphysical objectivity of the idea of good, taken as "what is useful to the powerful". The natural and legal component of political justice enters the philosophy of law only in the Florentine Renaissance.

Still, I am including the substance of Aristotelian imaginative theory within the strategy of formation and projection of the model of medieval imaginary, especially due to its pragmatic nature, for the following two reasons:

1. Containing much fewer technicalities than Plato's project, Aristotle's theory shifts the focus from the abstract model of the city on the reality of the family, oikos, and on social formation mechanisms. What I am considering as a fundamental strategy inside the medieval model of the imaginary in general, is the anthropological dimension of Aristotle's view on power in the social space (masculine-feminine, master-slave relations), focused as it is on the relationship between models and types, and not on individuals.

2. The medieval Romanian imaginary indicates the fact that Romanian society did not impose itself as an artefact (as in the case of Constantinople - an ideal city constructed according to a Platonic plan), but followed instead the natural social formation of the community, which 
resulted eventually in the superior state structure (this was Aristotle's "suggestion").

Accordingly, a practical thought, politically and civically exercised within the medieval community, encountered the Platonic ideas through the interpretation given by the Christian oikonomic plan. The various solutions for the organization of local oikonomia are reactions to the model of Byzantine power, rather complicated and abstracted, in the same manner as, mutatis mutandis, the practical Aristotelian philosophy reacted in his time to the Platonic utopia.

\section{Conclusions:}

The pragmatic foundation of the Romanian political-religious program thus followed, on the one hand, the path or natural configuration, and on the other, the path of residual (ancient) discursive formations, which traversed the political, thought of the Byzantine model up to our Middle Ages. Because of the mixture of high symbolic ideas and concrete historical pressure, the medieval Romanian imaginary gained a certain artificial mythologizing nature at the level of its models.

Nonetheless, the identification of recurring themes in official texts yields the self-image of the community a fundamental coherence. When we apply this research to the relationships between the internal "witnesses" of history, be they historiographic or iconographic, and other external ones (not only Byzantine and post-Byzantine, but Occidental as well), we can find answers to questions related to the semantic, thematic, philosophical and conceptual similarity between this imaginary and its medieval European model. The discursive formations or sets of common denominators, as well as the important philosophical dislocations in the interpretation of political power as a main factor in the organization of the world, might be able to show the extent to which the structure of different Christian medieval societies was similar. Moreover, we could better understand the heritage of the decisive meeting between ancient thought on power and JudaeoChristianity, apostolic tradition and the pressures of the imperial political system as well as, provided we follow some individual historical trajectories, the concrete differences between these medieval systems of power.

The matrix for the construction of the imaginary, conventionally divided into four horizontal levels (grouped two by two) and three vertical registers create the twelve modules or "open discursive fields", which we see as areas with their own individuality. They all converge towards the coalescent factor, the divine archetype, the supreme "One" (philosophically imagined from Parmenides to Romanian medieval theologians), warrantor of terrestrial authority and the identity image of the Christian community. 
Considering the nature of absolute truth of the "Word" (the Platonic Logos), the divine will and the value of Christ's sacrifice govern humanity and Christ prevails as supreme Judge on history and power, a hypostasis taken over by local autocrats.

By reflecting the relationship that the Romanian prince (whose main model is Constantine the Great himself) established, in the Christian imaginary, both with the terrestrial world and the supernatural world, the official power discourse offers the coordinates whereupon the model of the imaginary (which I am proposing) was built. In the model of the imaginary, the horizontal levels represent the following: the perceptible space, regulated either according to the anthropological model theorized by Aristotle (masculine-feminine, master-subject), or according to the symbolic model specific to the Middle Ages (culture-nature, inhabited space - unfamiliar space, private space-public space, profane space-religious space, concrete space-the space of "the next world" etc. Time is also involved in these spatial typologies by division into human time and ritual time, the time of knowledge or the time of penitence. I am introducing this particular perspective of multiple medieval time and space in order to continue the anthropological interpretation of the medieval model of the imaginary, which was completed with the fourth level, that of the fictional "imagined imaginary", where fantasy plays the main imaginative role.

The medieval Romanian imaginary uses the image, symbol and sign as fundamental morphological units for message transmission. The official discourse (religious iconography, religious exegesis, in time even historiography as historiae) is practiced as a sacred form of tradition and does not necessarily serve religious politics of proselytism, but most of all the "proselytism" of power and its political and ideological programs.

Based on this model, we can compare the medieval Romanian imaginary to any other type of imaginary of the time. By focusing on one or the other of the themes, one could gather data, which might provide images representative of the local mentalities, cultural and socio-political achievements.

Any comparison with the performances of Western art from the Protestant and Catholic area is futile, especially because of the incompatibility between the respective forms of expression, religious thought and specificities that we might not see as superior alternatives.

It would be more natural to do research on other Orthodox areas from the Balkans and the North of the Danube, without any attempts to give up the underlining of the mentality factors and types of imaginary, which condition the creation and dominants of local civilizations. Nevertheless, the comparison process founds in the common denominator - the politicalreligious plan of oikonomic governance of the Christian world - of both the post-Byzantine Orthodox space and the Western one. 
From the moment when the model of the imaginary is significantly changed, one could say that the mentality structures of a certain age are generally exhausted and antiquated. In the Romanian case, this disconnection - with all the humanist transformations and the cultural influences of Central and Western Europe or late "basileic" - remains, I believe, indebted to a medieval kind of thinking.

I have attempted this genealogical analysis of discursive formations and ideas/symbolic structures in order to prove that the medieval imaginary, as a reflection of a certain plan of Christian power - of Byzantine origin - of spiritual and material management of the oikonomia, inherited and implicitly preserved the national character of the ancient project of society-formation. The Romanian medieval world did not establish unmediated relationships with Greek philosophical thought on general politics, but only on image and divinity, and this one mostly through Palamite hesychasm. One can find in the practical formulation of community life and its identity image the basic facts, which would be eventually influenced by the model of the Christian Empire of Constantinople so that at last a local medieval imaginary was formed.

The community's system of thinking about itself and the relation with the other, though stereotyped - both because of the mnemonic rules of oral culture and to Orthodox commonplaces and their medieval interpretation left little room for local creativity and authentic imaginative trajectories. Under the close supervision of lay and religious institutions, these trajectories would remain almost unchanged in time. Still, the "residual" inheritance of Platonic structures, integrated and transformed within the Christian oikonomic plan, did meet the practical and pragmatic existential solutions at a local level (both political and socio-economic).

\section{Bibliography:}

Ahrweiler, Hélène, L'idéologie politique de l'empire byzantin, Presses Universitaires de France, Paris, 1975, trans. Cristina Jinga, Ideologia politică a imperiului bizantin, Corint, București, 2002.

Barbu, Daniel, Byzance, Rome et les Roumains. Essais sur la production politique de la foi au Moyen Âge, Babel, București, 1998.

Barbu, Violeta, "Lex animata et le remploi des corps", in L'empereur hagiographe. Culte des saints et monarchie byzantine et post-byzantine, New Europe College, București, ed. Petre Guran, 2001, p. 224-248.

Bréhier, Louis, La civilisation byzantine, $2^{\text {nd }}$ ed. Albin Michel, Paris, 1970.

Besançon, Alain, L'image interdite. Une histoire intellectuelle de l'iconoclasme, Libraire Arthème Fayard, Paris, 1994, trans. Mona Antohi, Imaginea interzisă. Istoria intelectuală a iconoclasmului de la Platon la Kandinsky, Humanitas, București, 1996. 
Browning, Robert, Justinian and Theodora, Praeger, New York, 1971, trans. Liliana Silvestri, Giustiniano e Teodora, Librex, Milano, 1974.

Chélini, Jean, Histoire religieuse de l'occident médiéval, Hachette, Paris, 1991.

Cizek, Eugen, Mentalităţi şi instituţii romane, Globus, București, 1998.

Dagron, Gilbert, Naissance d'une capitale. Constantinople et ses institutions de 330 à 451, Presses Universitaires de France, Paris, 1974.

Dagron, Gilbert, Empereur et prêtre. Étude sur le "césaro-papisme" byzantin, Gallimard, Paris, 1996.

Durand, Gilbert, L'imaginaire, Hatier, Paris, 1994, trans. Anna Chiara Peduzzi, L'immaginario. Scienza e filosofia dell'immagine, RED, Como, 1996.

Durand, Gilbert, Les structures anthropologiques de l'imaginaire, Dunod, Paris, 1992, trans. Marcel Aderca, Structurile antropologice ale imaginarului. Introducere în arhetipologia generală, Univers Enciclopedic, București, 1998.

Eco, Umberto, La definizione dell'arte. Dall'estetica medievale alle avanguardie, dall'opera aperta alla morte dell'arte, Garzanti, Roma, 1972;

Eco, Umberto, Arte e bellezza nell'estetica medievale, Bompiani, Milano, 1987, trans. Cezar Radu, Arta şi frumosul în estetica medievală, București, Meridiane, 1999.

Eliade, Mircea, Le sacré et le profane, Gallimard, Paris, 1965, trans. Rodica Chira, Sacrul şi profanul, Humanitas, București, 1992.

Ferraris, Maurizio, L'immaginazione, Il Mulino, Bologna, 1996.

Grabar, André, L’iconoclasme byzantine, Flammarion, Paris, 1984, trans. Daniel Barbu, Iconoclasmul bizantin, Meridiane, București, 1992.

Le Goff, Jacques, Pour un autre Moyen Âge, Gallimard, Paris, 1978, trans. Maria Carpov, Pentru un alt ev mediu. Valori umaniste în cultura şi civilizaţia evului mediu, Meridiane, București, 2 vols, 1986.

Le Goff, Jacques, L'imaginaire médiéval, Gallimard, Paris, 1985, trans. Marina Rădulescu, Imaginarul medieval, Meridiane, București, 1991.

Lavaud, Laurent, L'Image, Flammarion, Paris, 2000.

Maffei, Fernanda, L'arte bizantina nell'età di Giustiniano, Giunti, Firenze, 1988.

Manolescu, Nicolae, Istoria critică a literaturii române, vol. I, Minerva, București, 1990

Mesina, Laura, "Imaginarul ca formă de 'narare' a istoriei. Propunerea unui model cibernetic", in Analele Universităţii Bucureşti, XLXX, 2001, Editura Universităţii din București, București, p. 49-60.

Mondzain, Marie-José, Image, icône, économie. Les sources byzantines de l'imaginaire contemporain, Seuil, Paris, 1996.

Narducci, Emanuele, "Il pensiero politico romano tra repubblica e impero", in Il pensiero politico dell'età antica e medioevale, UTET, Torino, 2000, ed. Carlo Dolcini, p. 99-121.

Paul, Jacques, L'Église et la culture en Occident, Presses Universitaires de France, Paris, 2 vols., 1994.

Piccini, Gabriella, I mille anni del Medioevo, Mondadori, Milano, 1999.

Pippidi, Andrei, Tradiţia bizantină în ţările române în secolele XVI-XVIII, Corint, București, 2001.

Ravegnani, Giorgio, La corte di Giustiniano, Jouvance, Roma, 1989.

Seneca, Lettere a Lucilio, Rizzoli, Milano, trans. G. Monti, 1985.

Spector, Céline, Le pouvoir, Flammarion, Paris, 1997. 
Tacit, Tutte le opere, Sansoni, Milano, ed. E. Cetrangolo, 1993.

Talbot Rice, David, Byzantine Art, Penguin Books, Norwich, 1968.

Tristan, Frédérick, Les premières images chrétiennes, Librairie Arthème Fayard, Paris, 1996, trans. Elena Buculei, Ana Boroş, Primele imagini creştine. De la simbol la icoană, secolele II-IV, Meridiane, București, 2002.

Zanetti, Gianfrancesco, "Il pensiero politico di Aristotele", in Il pensiero politico dell'età antica e medioevale, UTET, Torino, 2000, ed. Carlo Dolcini, p. 35-70.

Zumthor, Paul, La mesure du monde, Seuil, Paris, 1993. 